\title{
噴霧塗装指導標準について \\ Guide for Spray Coating from Viewpoint \\ of Exhaust Gaseous Properites
}

\section{1. は じめに}

わが国の公害は最近急激に増加し，産業特よび人口の 都市集中, 新産業都市の開発などによって, 特に大気污 染状況は年々悪化の傾向にあり，亜硫酸ガスに加えて， 最近では自動車排気ガスなどの問題も発生して，その防 止対策の強化が急がれている。

43 年 6 月, 国では, 公害対策基本法に基づく, 「大気 污染防止法」を制定, 12 月 1 日から施行されている。

一方, 地方条例として, 東京都では昨年 6 月に「東京 都公害防止条例」を都議会で可決，公害に対する規制は 一層きびしくなりつつある。

\section{1）広域污染と局地污染}

一般に大気污染は，発生源の種類叔よび分布，污染機 構から判断して, 広域污染と局地污染炕分類され, 対策 面でも二つに分けた方が実施しやすい。

広域污染は，その都市なり地域での主要燃料，産業の 種類, 污染源の性質, 自動車走行状況, 地形, 気象条件 などによって特有なタイプを持つ。ロンドン型，ロスア ンジェルス型などで代表されるるのや，東京都のように その混合型の中間的なものなぞ発生機構はなかなか複雑 であるが，東京都は徐々にロスアンジェルス型に移行し つつある。これらの防止対策として，燃料中のイオウ分 の規制, 重油の脱硫, 自動車排気ガス規制, など, 不特 定多数の発生源に対して, 政治的, 行政的手段により防 止することが多い。

これに対し局地污染は, 特定発生源からの多種類のば い煙，有害ガスなどによって特定の地域住民に被害を与 えることが多い。噴霧叙装に伴う粉じん，臭気など良い? 例である。

\section{昭 44.10 .6 受理}

* 東京都首都整備局公害防止計画部 千代田区丸/内 3 - 1

\section{菱田一雄* HISHIDA Kazuo}

局地污染は, 広域污染の一部の原因であり, 広域污染 の範中で考えて良いが，局地内の発生源に対する大気污 染防止対策は, 技術的, 経済的な面が大きい。局地污染 は工業地域内の発生件数が多いが, 商業地域や, 住居地 域でも特定の発生源の影響を受け, 苦情, 陳情となって 現われることが多い。表-1，2，3 亿東京都昨年度申 立のめった苦情のうち、すす・ばい煙を除いた粉じんと 臭気の業種別件数と, 指導内容を示す。

表-1 粉じん発生作業と苦情処理件数（昭和 43 年）

\begin{tabular}{|c|c|}
\hline 粉 ごんの発生作 業 & 件 数 \\
\hline 製綿・古綿作業（綿粉じん） & $18(9.5 \%)$ \\
\hline 木材・家具などの加工（木くず・粉じん） & $16(8.4 \prime \prime)$ \\
\hline 化学工業・ゴムなぞの製造(原料・擎品粉じん) & $10(5.3 \prime \prime)$ \\
\hline 石・レンガなどの粉确（砂じんなど） & $23(12.1 \prime \prime)$ \\
\hline 金属研摩作業（金属粉じん） & $17(8.9 \prime \prime)$ \\
\hline バフ $\quad l \quad($ バフ & $3(1.6 \prime \prime)$ \\
\hline 塗料の吹付作業（塗料＂） & $77(40.5 \prime \prime)$ \\
\hline そ の & $26(13.7 \prime \prime)$ \\
\hline 計 & $190(100 \%)$ \\
\hline
\end{tabular}

表-2 ガス・臭気関係苦情処理件数

\begin{tabular}{|c|c|c|c|}
\hline $\begin{array}{l}\text { ガス(臭気) } \\
\text { 発生工程 }\end{array}$ & 件 数 & $\begin{array}{ll}\text { ガ } & \text { (臭気) } \\
\text { 発 } & \text { 生 I程 }\end{array}$ & 件 数 \\
\hline $\begin{array}{l}\text { 無機 化 学 } \\
\text { 有 機 化 学 } \\
\text { 金属表面処理 } \\
\text { 魚腸骨獣骨関係 } \\
\text { 食 料 油 脂 } \\
\text { 一般食料品製造 } \\
\text { 印 刷 業 }\end{array}$ & \begin{tabular}{|}
$81(16.7 \%)$ \\
$66(13.6 \prime \prime)$ \\
$92(19.0 \prime \prime)$ \\
$2(0.4 \prime \prime)$ \\
$12(2.5 \prime \prime)$ \\
$11(2.3 \prime \prime)$ \\
$21(4.3 \prime \prime)$
\end{tabular} & 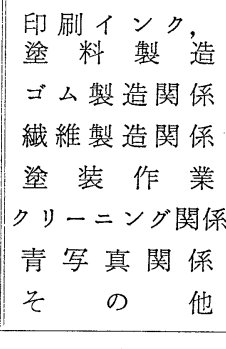 & $\begin{array}{l}21(4.3 \%) \\
7(1.5 \prime \prime) \\
4(0.8 \prime \prime) \\
65(13.4 \prime \prime) \\
12(2.5 \prime \prime) \\
15\left(3.1^{\prime \prime}\right) \\
75(15.6 \prime \prime)\end{array}$ \\
\hline & & 計 & $484(100 \%)$ \\
\hline
\end{tabular}


表-3 塗装関係粉じん・臭気指導事項

\begin{tabular}{|c|c|c|c|c|}
\hline \multicolumn{2}{|c|}{ 指導事項 現 象 } & 粉じん & 臭 & 気 \\
\hline \multirow{3}{*}{$\begin{array}{l}\text { 届 } \\
\text { 出 } \\
\text { 関 } \\
\text { 係 }\end{array}$} & 工場の移転指示 & 24 & 15 & \\
\hline & 認 可関 係 指 示 & 8 & 8 & \\
\hline & 届＼cjkstart出 & 0 & 2 & \\
\hline 発 & 機 械 変 更 & 2 & 0 & \\
\hline 生 & 発 生 源 の改善 & 2 & 2 & \\
\hline 源 & 原 材 料 の変更 & 2 & 0 & \\
\hline \multirow{2}{*}{$\begin{array}{l}\text { 作 } \\
\text { 業管 } \\
\text { 理 }\end{array}$} & 作 業 中 止 & 11 & 9 & \\
\hline & 作 業 管 理 注意 & 38 & 33 & \\
\hline \multirow{5}{*}{$\begin{array}{l}\text { 処 } \\
\text { 理 } \\
\text { 施 } \\
\text { 設 }\end{array}$} & 処理 施設設置 & 28 & 25 & \\
\hline & 処理 施設改善 & 21 & 12 & \\
\hline & 処理施設の保守管理 & 15 & 2 & \\
\hline & 処理施設の操作注意 & 2 & 1 & \\
\hline & 排 気䉍 の 改善 & 5 & 4 & \\
\hline \multicolumn{2}{|l|}{ そ } & 4 & 3 & \\
\hline \multicolumn{2}{|c|}{ 合 } & 162 & 116 & \\
\hline
\end{tabular}

この表の大部分は, 中小規模の工場で, 技術的, 経済 的，法規的な面で問題となりやすいが，大規模工場など では技術的管理的な面に掠ける不備なるのも数が多い。 指導事項の件数が，処理件数の合計より多いのは，同一 工場に対して 2 以上の指導を行なうことがあるからであ る。

\section{2）ばい煙および工場排ガス処理施設指導標準の必要} 性

都では，都内に設置されている大気污染形の工場など から発生されるばい煙（すす・粉じん）, 有害ガス, 悪 臭なぞに対して, 処理施設の設置を指導し, 企業側の努 力もあって, ばい煙あるいは, 工場排ガスの処理施設を 設置している工場はかなり増加している。しかしなが ら, 小規模な町工場, あるいは処理施設などが不完全な ものなどの発生源の指導にあたっては，標準的，かつ適 嫼 正な処理施設を選定し，行政指導の基準となり，また施 䍂 設責任者が，経済的な実用性のある処理施設を選定でき るような, 目やすをあたえる指導標隼を作成する必要が偂 ある。また，都に打ける公害防止条例が，各区役所権 限を移譲したとき，区によって，指導状沉に差があってい は，都全域の公害行政にはマイナスである。各区拈よび、 個人差を無視した標準的な技術指導が望ましい。

\section{3）指導標準の考え方}

都の指導標準の特徵と, 配慮した点を示すと,

処理施設の選定に際しては，効率とともに経済性を考 慮に入れて, 一般の処理施設では, 都の貸付金の限度額

300 万円以下で設置可能なるのとし，臭気，工場排ガス のように排出基準のないものは，現在の処理技術で最も 妥当と思われる排出濃度を規定した。乙かし大規模なも のは, 比較的高度なもの, 小規模なものは, 容易に設置 しうるように考慮してある。

表現は，専門的知識を有しないるのでも理解しやすい ようにできるだけ平易にし，参考資料として，発生源の 状況, 作業工程, 作業条件, 污染質の化学的, 物理的性 状, 測定法, 関係法規などの条項を例示し, また適切な フードの設置, 有害ガスの危険度と発生度などを考慮し た。

昭和 44 年 3 月までにばい煙については, 平炉, 電気 炉, 鋳鉄用溶銑炉, 骨材乾燥炉, 非鉄金属関係炬（銅合 金，鉛再製鍊，アルミニウム二次製錬），ごみ焼却炉， ボイラー，溶融亜鉛メッキなどを作成し，工場排ガスに ついては, 塩化水素, アンモニア, クロム酸ミスト, 窒 素酸化物, 硫化水素, フッ素化合物, 噴霧塗装などを作 成してきた。

作成の手順として, 都知事の諮問機関である, 東京都 都市公害対策審議会に, 指導標準はどうめるべきかを諮 問し, 同会の大気污染部会, 同工場など小委員会が原案. を作成, 総会と怙いて答申となり, 都知事が採用ずると いう形式になっている。

したがって, この「噴霧叙装工場排煙処理施設指導標 準」(以下略して噴霧塗装指導標準という）は，工場な ぞ小委員会, 噴霧叙装指導標準作成分科部会が担当し! た。

昭和 43 年 6 月 10 日から数回にわたって検討会を開 催, 一方都市公害部に秃いて, 各施設の排ガス, 除害効 率なぞを測定，その性状を徹底的に調查し，資料を委員 会に提出, 各委員の意見を調整し, 実現可能な処理施設 を決定した。作成にあたっては，つぎの委員が各分野を 担当した。

（専門委員）

東畑平一郎

大野長太郎

(外部委員)

鈴木 成一

剣持 雄治

橋爪稔

岩 崎毅

加藤征太郎

（事務局）

$\begin{array}{lrl}\text { 菱田 } & \text { 一雄 } & \text { 東京都都市公害部 } \\ \text { 武田 実 } & \text { 同 上 }\end{array}$

中央大学理工学部教授

（株）日立製作所

鈴木成一化学技術士事務所 岩田叙装機工業(株)

労働省学衝衛生研究所 労働省学衝衛生研究所 中央大学理工学部

同上 
中野 金三 東京都都市公害部

大原 俊男同上

\section{2. 噴霧塗装指導標準（全文 188 頁）}

（1）内 容

I 噴霧塗装の排煙処理施設 (本文)

1）噴霧塗装の粉じん

2）噴霧塗装の溶剤臭

II 噴霧塗装の排煙処理施設選定の理由

III 噴霧塗装の排湮処理施設の実施例

1）噴霧塗装の粉じん処理施設

2）噴霧塗装の溶剂臭処理施設（以上 $1 \sim 10$ 頁）

IN 参考資料

（参考資料）

1) 塗装および機器 $(11 \sim 48$ 頁 $)$

2）噴霧塗装の粉じん括よび溶剤の性状

(49 80 頁)

3）噴霧塗装の粉じんおよび溶剂処理施設

$(81 \sim 122)$

4）塗装粉じんおよび有機溶剤の測定例

$(123 \sim 172)$

5）関係法令

(173 188)

以下に指導標準の概要について述べる。

（2）噴霧塗装の排煙処理施設（本文）

1）噴霧塗装の粉じん

湿式（水洗式）または乾式（口過式）処理施設（噴霧 塗装用ブース）と排気筒とする。また，作業中における 粉じんの排気筒の出口の濃度を,

$$
\begin{array}{lr}
\text { 平均 } & 75 \mathrm{mg} / \mathrm{Nm}^{3} \\
\text { 上限 } & 150 \mathrm{mg} / \mathrm{Nm}^{3}
\end{array}
$$

以下とする。

\section{2）噴霧塗装の溶剂濃度}

工場境界線において, 有機溶剤の濃度は, 労働環境許 容濃度の $1 / 10$ ，または 1 時間平均值の $1 / 100$ 以下に保 つような排気筒とする。また，それ以上の濃度になると きは, 燃焼法, 吸着法, 接触酸化法などによって有機溶 剤の排出濃度を低減する方法を考慮しなければならな Wo

（3）噴霧塗装の排煙処理施設選定の理由（本文）

塗装噴霧に伴う污染物質は，分散された塗料自体とそ れにより発生した有機溶剤の蒸気である。

塗料噴霧の粒度は通常の塗装施設では, $100 \mu \sim 200 \mu$ が理想とされている。したがって塗装粉じんについての み見れば, 特に強風でもない限り, 遠距離までは污染し ない。しかし, 近隣に対しては污染を生ずる恐れがある。 現時点では湿式ブースが多く用らいられている。この装

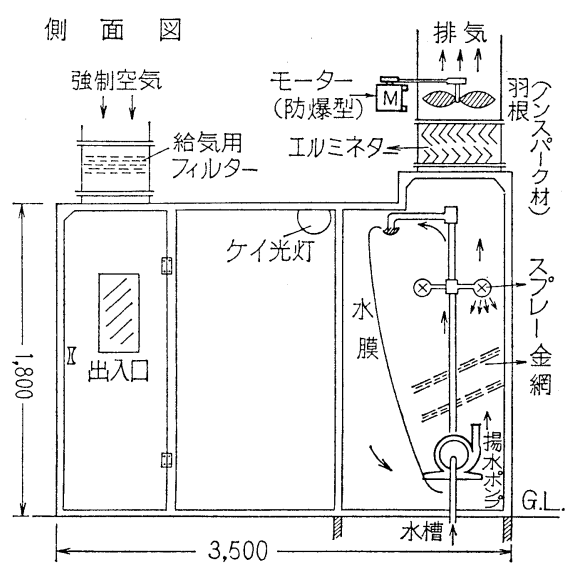

仕 様

密閉式強制給気型水洗ブース

寸 法 W $3500 \times \mathrm{L} 3500 \times \mathrm{H} 1800$

排気扇 $155 \mathrm{~m}^{3} / \mathrm{min}$ モーター $200 \mathrm{~V} 3 \phi 0.75 \mathrm{~kW}$ 揚水ポンプ $200 \mathrm{~V} 3 \phi 1.5 \mathrm{~kW}$

$$
\begin{array}{ll} 
& \text { 安全增防爆型 水量 } 1.5 \mathrm{~m}^{3} / \mathrm{min} \\
\text { 照 明 } & \text { ケイ光灯 } 100 \mathrm{~V} 40 \mathrm{~W} 2 \text { 個 } \\
\text { フィルター } & \text { ナイロン製 } 10 \text { 枚 } \\
\text { 水 膜 } & \text { 厚 } 3 \mathrm{~mm} \\
\text { 備 考 } & \text { 電気配線, 機器類は全部防爆型とする } \\
\text { 図-1 水洗ブース (密閉式強製給気型) }
\end{array}
$$

置は，規模，作業方法などにより異なるが，たいていの 規模，作業方法に合致するものが市販されている。

また，有機溶剤については，たとえば湿式ブースを使 用しても，ほとんど捕集できず，しばしば污染の原因と なる。これの処理施設は理想的なものがなく, やむを得 ない場合を除いては, 排気筒を用いて大気拡散を行なら 方法を採用した。

\section{（4）噴霧塗装の排煙処理施設の実施例}

密閉式強制給気型の水洗ブースによる粉じん処理施設 の一例を図-1 に示す。

\section{3. 塗装と機 器}

\section{（1）塗装の種類と特性}

1）金属塗装

金属塗装は船舶, 車輛, 自動車, 電気製品, 工作機械 およびその部品など塗装関係では最も広い分野にわたっ て扣り，それぞれの分野に適応した塗装方法预よび機器 を選ばなければならない。できらる限り効率の良い経済 的な電気的塗装や，自動化などによって，発生源に蛙け る飛散を少なくすることが大切である。表-4 に塗装の 種類と公害についての関係表を示す。

2）建築塗装 
表-4

\begin{tabular}{|c|c|c|c|}
\hline & 細 & 環 & 公 \\
\hline エアスプレー & $\begin{array}{l}\text { 外 部 混 合 式 } \\
\text { 内 部 混 合 式 } \\
\text { (本文参照) }\end{array}$ & 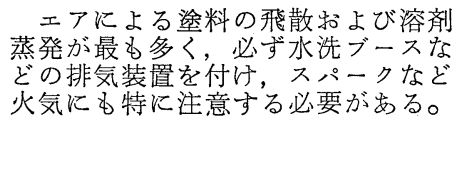 & 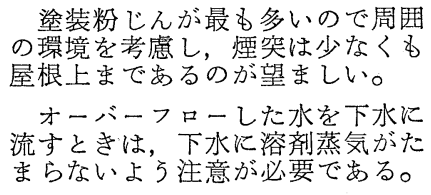 \\
\hline エアレススプレー & $\begin{array}{l}\text { ホットエアレス } \\
\text { コールドェアレス } \\
\text { (本文参照) }\end{array}$ & $\begin{array}{l}\text { ×アスプレーよりは少ないが飛散 } \\
\text { および溶剤蒸発が相当あるのでェア } \\
\text { スプレーと同様な装を取り付ける } \\
\text { 必要がある。 }\end{array}$ & 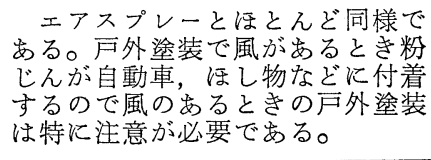 \\
\hline 静電スプレー & $\begin{array}{l}\text { 手 持 型 静 電 } \\
\text { 定 置 型 静 電 } \\
\text { (本文参照) }\end{array}$ & 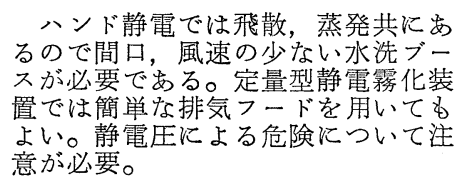 & $\begin{array}{l}\text { ェア,ェアレスに比較し公害間 } \\
\text { 題は少ない。しかし浴剤蒸発は同 } \\
\text { じである。 }\end{array}$ \\
\hline 浸セキ塗装 & $\begin{array}{l}\text { 溶 剤 塗 料 型 } \\
\text { 水 性 塗 料 型 }\end{array}$ & 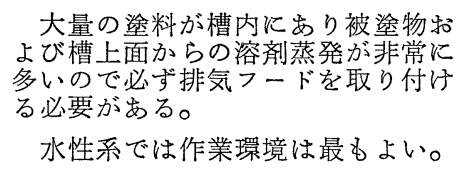 & 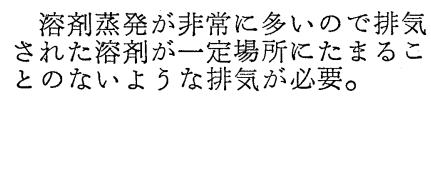 \\
\hline & デフロコーター & $\begin{array}{l}\text { 塗装室が別途設けられるので作業 } \\
\text { 環境はよいが涪装室からの排気が必 } \\
\text { 要。 }\end{array}$ & 浸セキ塗装に同じ。 \\
\hline & $\begin{array}{l}\text { カーテン } \\
\text { フローコーター }\end{array}$ & 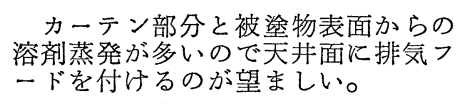 & $\begin{array}{l}\text { 溶剤蒸気が下にたまらないよう } \\
\text { 注意が必要。 }\end{array}$ \\
\hline & ローラーブラッシ & ハヶ塗りと同じで作業環境はよい。 & 公害の問題はほとえどない。 \\
\hline & ローラーコーター & $\begin{array}{l}\text { カーテンプローニーターとほとん } \\
\text { ぞ同じである。 }\end{array}$ & $\begin{array}{l}\text { カーテンフローコーターとほと } \\
\text { んど同じである。 }\end{array}$ \\
\hline 自 動 塗 装 & & $\begin{array}{l}\text { 塗装部分には必ず排気フードまた } \\
\text { は永洗ブースなどが取り付けられ塗 } \\
\text { 装部分は無人となる。 }\end{array}$ & $\begin{array}{l}\text { 塗装部分がェア,ェアレス, 静 } \\
\text { 電によって異なりそれぞれのスプ } \\
\text { レーの場合と同じである。 }\end{array}$ \\
\hline 電 着 臸 装 & & $\begin{array}{l}\text { 水性塗料であるが, アミンなどの } \\
\text { 蒸発があるで,やはり排気フード } \\
\text { を取り付けるが望ましい。 }\end{array}$ & $\begin{array}{l}\text { 塗装粉じん溶剤蒸気の問題はな } \\
\text { 差後の水洗工程で排に } \\
\text { 叙料が混入て着着色されるので, } \\
\text { 適切な排水処理が必要である。 }\end{array}$ \\
\hline \multirow[b]{2}{*}{ 粉 体 塗 装 } & 流 動 漫 セ キ & $\begin{array}{l}\text { 粉体は槽内のみであるので作業環 } \\
\text { 境は最もよいるのの一つである。 }\end{array}$ & $\begin{array}{l}\text { 戸外には全く関係なく公害問題 } \\
\text { は全くない。 }\end{array}$ \\
\hline & 静電粉体 スプレー & 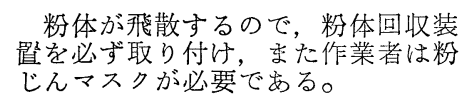 & 流動浸セキと同じ。 \\
\hline
\end{tabular}

建築塗装は素地面からみると非常に多彩で, 塗装工程 からみると広範团にわたっている。しかし金属塗装ほど の塗面が要求されるところは少なく, 従来一般にハケ塗 装が多く，ハケ目をできるだけ目立たないように仕上げ るのが常識的条件の一つである。塗料も調合ペイントが 最も多く使用されている。エア・スプレー, エアレス・ スプレーなどによる塗装では塗料が飛散するので, 風の
めるときは外装を行なってはならない。

\section{3）木工塗装}

木工塗装では，ほとんぞが塗装方法および塗装機器が 限定されるので, 水洗式のスプレーブースを取り付けて 行ならべきである。浸セキ塗装, フローコーターなどに より能率向上を計り, 経済的, 衛生的な方法も採用すべ きである。 


\section{（2）エア・スプレーの種類と構造}

エア・スプレーガンは大きく分けて同じ圧縮空気を用 いて塗料を霧化するのに塗料と空気を空気キャップの外 側で混合微粒化する外部混合式とその反対の内部混合式 スプレーガンとに分けられる。一般塗装用には大半が外 部混合式スプレーガンが用いられ, 内部混合式スプレー ガンは主に特殊塗料の吹き付けに用いられる。

スプレーガンの能力は空気使用量, 塗料噴出量がその 基本となるが，それらは本体の大きさ，塗料供給方式， ノズルロ径によって定められる。簡単な表にまとめたも のが表-5 で, 大型スプレーガンは $1.5 \mathrm{~kW}$ 以上の空気 圧縮機が必要である。圧送式は吸上・重力式に比し塗料 ノズルロ径が小さいが塗料噴出量, 空気使用量, スプレ 一パタン開きとも大きくなっている。

\section{（3）エアレス・スプレーの種類と構造}

エアレス・スプレー装置は用途, 使用塗料の性質, 被 塗装物の大ささ, 形状, 使用場所によって, 使用する塗 料加圧のためのプランジャーポンプが大型, 中型, 小型 および圧力倍率の異なる高圧型, 中圧型などと使い分け る。またコールドスプレー型と, ホットスプレー型に分 けることもできる。

パタンの大ささと噴出量はノズル・チップの内部形状 と孔形状によって決められる。ホットスプレー型はポン プとスプレーガンの間にヒーターが組み达まれて抢り， (70 $\left.80^{\circ} \mathrm{C}\right)$ 粘度を下げて噴射している。

パタン開きは塗料圧力の変化に対し図-2・に示すよう にあまり変化しないので，パタン開きを変光る場合はノ ズル・チップを交換する。噴霧粒子径は塗料生力の高い ほぞ平均粒径は小さくなり，高粘度ほど粒子が荒くなる とともに，パタン中心と端の粒径差が大きくなる。

図-3 に塗料圧と粒子径の関係を示す。

\section{(4) 焼付乾燥施設}

焼付乾燥施設には赤外線方式と熱風発生方式の 2 方式 があって，その種類と構造はつぎに示めすように分類さ

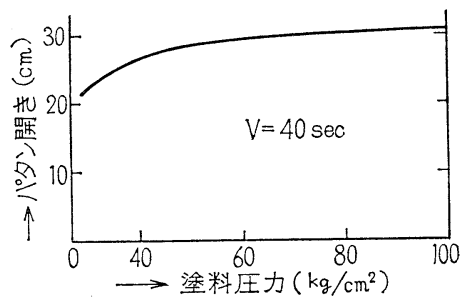

図-2 塗料圧力とパタン開き

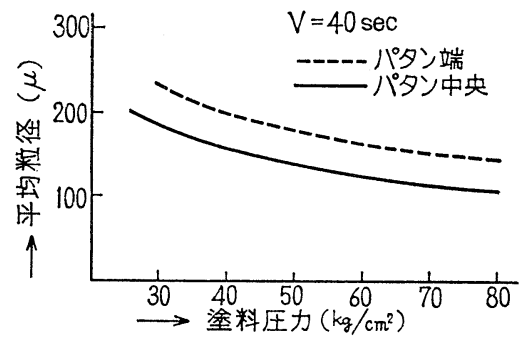

図-3 塗料圧と粒子径

れる。

(1) 赤外線方式

ア赤外線ランプ

ガス赤外線

最高温度 $\quad 180^{\circ} \mathrm{C}$

ウ 遠赤外

同 $200^{\circ} \mathrm{C}$

同 $500^{\circ} \mathrm{C}$

(2) 熱風発生方式

ア間接式 $\mathrm{a}$ 循環式蒸気同 $150^{\circ} \mathrm{C}$

空気同 $170^{\circ} \mathrm{C}$ 油ガス同 $350^{\circ} \mathrm{C}$ b 非循環式 蒸気 同 $130^{\circ} \mathrm{C}$ 空気 同 $150^{\circ} \mathrm{C}$ 油ガス 同 $250^{\circ} \mathrm{C}$

1 直接式 $\mathrm{a}$ 循環式 油ガス 同 $600^{\circ} \mathrm{C}$ b 非循環式 油ガス 同 $600^{\circ} \mathrm{C}$

熱風発生炉の熱源には電気，都市ガス，石油ガス，天 然ガス，油などが使用されるが，直接式炉には特に白灯

表-5 ス プレ・ガン能力

\begin{tabular}{|c|c|c|c|c|c|c|c|}
\hline $\begin{array}{c}\text { 本 体 の } \\
\text { 大きさ } \\
(\mathrm{g})\end{array}$ & $\begin{array}{c}\text { 塗 料 } \\
\text { 供給方式 }\end{array}$ & $\begin{array}{c}\text { 塗 料 } \\
\text { ズル口径 } \\
(\mathrm{mm} \phi)\end{array}$ & $\begin{array}{c}\text { 塗量噴出量 } \\
\text { (ml/min) }\end{array}$ & $\begin{array}{c}\text { 空気使用量 } \\
(l / \mathrm{min})\end{array}$ & $\begin{array}{c}\text { 使用空気圧力 } \\
\left(\mathrm{kg} / \mathrm{cm}^{2}\right)\end{array}$ & $\begin{array}{c}\text { スプレーパタ } \\
\text { ーン開き } \\
(\mathrm{mm})\end{array}$ & $\begin{array}{c}\text { 所 要 } \\
\text { コプレッサー } \\
(\mathrm{kW})\end{array}$ \\
\hline \multirow{2}{*}{$\begin{array}{c}大 \quad \text { 型 } \\
(600 \sim 800)\end{array}$} & $\begin{array}{l}\text { 重力式 } \\
\text { 吸上式 }\end{array}$ & $1.3 \sim 2.5$ & $\begin{array}{c}120 \sim 230 \text { 以上 } \\
(400)\end{array}$ & $280 \sim 340$ & $3.0 \sim 4.0$ & $\begin{array}{c}150 \sim 230 \text { 以上 } \\
(300)\end{array}$ & $1.5 \sim 2.2$ \\
\hline & 圧送式 & $1.0 \sim 1.6$ & $\begin{array}{c}250 \sim 600 \text { 以上 } \\
(1000)\end{array}$ & $250 \sim 500$ & $3.5 \sim 4.5$ & $\begin{array}{c}200 \sim 320 \\
\quad(450)\end{array}$ & $2.2 \sim 3.7$ \\
\hline \multirow{2}{*}{$\begin{array}{c}\text { 小 型 } \\
(200 \sim 400)\end{array}$} & $\begin{array}{l}\text { 重力式 } \\
\text { 吸上式 }\end{array}$ & $0.5 \sim 1.6$ & $\begin{array}{c}15 \sim 130 \\
(250)\end{array}$ & 200 以下 & $2.5 \sim 3.5$ & $\begin{array}{l}15 \sim 140 \\
(200)\end{array}$ & $0.2 \sim 1.5$ \\
\hline & 压送式 & $0.7 \sim 1.0$ & $\begin{array}{c}140 \sim 200 \\
(400)\end{array}$ & $100 \sim 290$ & $3.0 \sim 4.0$ & $\begin{array}{c}140 \sim 170 \\
(350)\end{array}$ & $0.75 \sim 2.2$ \\
\hline
\end{tabular}

$10[1]$ 
油軽油なぞが適している。間接炉は不完全燃焼によるば い煙を炉体内に入れないこと，燃焼の炎が未燃焼ガスに ふれ燥発を起こすような危険が少ないことなどの長所を もつ反面, 熱効率が低く, 対流炉は赤外線の幅射に比べ て遅く, 被塗装物の昇温に時間が長くかかることが欠点 である。直接炉は間接炉に比べて熱効率の高くなる利点 があるが, 熱交換器を通過しないため燃料が未燃焼のま ま炉内にたまる危険がある。特に都市ガスを燃焼させる ときは特注意することが肝要である。不完全燃焼によ って塗面に悪影響を及ぼし，ガスチェックによる塗面の 縮み現象が起こる場合がある。

\section{4. 粉じんおよび溶剤の性状}

\section{（1）粉じんの一般的性状}

噴霧となった塗料は，20１00\% のシンナーを使用直 前に加兄られているので, 微細滴は単位質量当りの表面 積がきわめて大きくなり, 滴の表面から溶剤の蒸発が促 進される。この場合の蒸発速度, 温度降下（場合により 上昇）と霧滴の細かさとは密接な関係にあるが，カンと 経験に頼ることが多く理論的にわからないことがたくさ んある。

飛行中の塗料噴霧粒子の大きさを直接に高速度写真に 顕微鏡技術を併用して測定した例もあるが，集合体とし て噴霧パタンの微粒化状態を調べる場合は, シャッター, 後方に置いたガラス板，あるいは全紙程度の大きい紙に 塗着したパタン各部をいずれも拡大鏡で調べると，この 場合に微粒子は空気流の方向が直角に曲げられるとき同 伴されるから, 微細部の一部は大気中に放出される結果 となる。

また噴霧となった塗料は，半分以上の溶剂を含んだ液 滴であるから, 飛行中は扁平状, 紡すい状などの形を周 期的に振動しながら变化していると考兵るべきである。 变形度, 周期などは粒径, 表面張力, 密度, 粘度なぞに 関係しているといわれている。したがって粒子が，壁に 衝突したときは，付着した粒子の大きさと，飛行中の滴 の大きさとは違うと考える方が妥当である。

\section{（2）霧化塗料の粒径}

塗装噴霧をガラス板めるいは紙に塗着させたパタン内 の粒子の分布状態を調べると，微粒から粗粒をでかなり 広い範囲に打いていわゆる粒度分布をしている。

亀井は好ましくは, 上, 中, 塗りは $200 \mu$ (平均), 上 塗り $150 \mu$ (平均) が良好な噴霧状態に近いことを述べ ている。パタンを適当とし, 滴の分布密度を均一とな し, 粒径分布の最大値（上限値, 下限値の算術平均）を 示す粒径と理解される。
（塗装技術，第 1 巻，第 1 号，66 頁 (1962))。

萩原は静電霧化した塗料の液滴を受けとめるのに, 非 水溶液ではアルコール汇高濃度アクリル酸ナトリウム溶 液を加えたものを, 水溶液ではシリコーン油を使用し, ほぼ球形の滴を捕集し, 約 300 個の測定值から個数平均 径の出現頻度の\%と粒径の関係を調べている。

普通痕跡を測定したデータにより $100 〜 150 \sim 200 \mu$ 程 度の塗料粒子が最も出現頻度が高いような噴霧状態のと き最も良好な塗膜を得ると考学る人が多い。

ここで萩原のデータを計算すると表面積平均径 $105 \mu$, 算術平均径 $82 \mu$ となる。また図-4 から明らかなように 最も出現頻度の大きい粒径は $50 \mu$ であることがわかる。 （色材協会誌 37 巻 6 号 p. 216 224 (1964))。

衝突法によって塗料粒子を測定する場合には, 塗料滴 は空気中で振動をつづけ, 衝突により变形を生じ, 120 〜 130\% の粒径として痕跡をつくるものと考兄られる。 塗料滴が空気中で球形をなすものと仮定して, 痕跡径を 球径逆算すると, 龟井の值は痕跡径群のらち出現頻度 の大きいものを取っているのにもかかわらず（100/120 ～130）の縮少により上記表面積平均径 $(105 \mu)$ 飞偶然 近似する。

\section{（3）塗料の物理的, 化学的性質}

生塗料の物性は良く知られているが，ここで必要なの

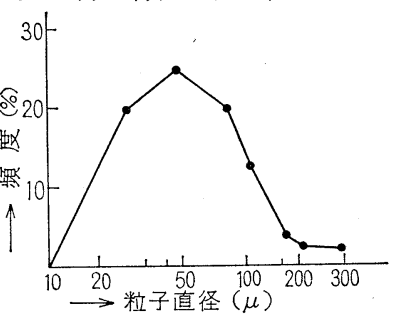

図-4 䊚子直径と出現頻度
は, シンナー希釈し て噴霧塗装を行なら 際の物性である。 塗料は通常多数の 配合成分を混合して つくる。1 品種につ いて 10 数種あるい は, 数 10 種類の原 料を混合するような組成を有する塗料は決して珍らしく ない。大別して，(1) 固体顔料粒子，(2)結合剂, ビヒ クルあるいはバインダーと称せられるもの，(3)溶剤の 3 種類と考光らるであらう。

(1) 顔料……般にミクロン $(\mu)$ 程度の一次粒子 と, $10 \sim 20 \mu$ 程度の二次粒子との単独または, 混合物で める。その粒径と比重を測定した值は表-6 のと扮りで ある。粒子は一次粒子であるが, 最小と最大には大きな 差がある。

（2）結合剤……然物誘導体や，各種の合成樹脂な ぞの高分子物質を化学的に結合させて使用する。一般に 分子量は $2,000 \sim 5,000$ 程度のものを溶剂に溶解または 分散した状態で使用する。分子量が数万程度にもなる と, 特殊な溶解力の強い溶剤を必要とするから, 特別な 
表-6 顔料の粒径と密度

\begin{tabular}{|c|c|c|}
\hline 顔 & 粒 径 $\mu$ & 密度 $\mathrm{g} / \mathrm{cm}^{3}$ \\
\hline 炭酸カルシウム & $0.1 \sim 0.15$ & $2.6 \sim 2.7$ \\
\hline チタン白 & $0.1 \sim 0.8$ & $4 \sim 4.2$ \\
\hline 覀 & $0.1 \sim 5$ & $5.5 \sim 5.6$ \\
\hline 鉄 系 顔 料 & $0.1 \sim 1.0$ & $4.5 \sim 5.2$ \\
\hline クロム系顔 料 & $0.1 \sim 2.0$ & $3 \sim 3.3$ \\
\hline カーボンブラック & $0.02 \sim 0.1$ & $1.8 \sim 2.1$ \\
\hline 有 機 顔 料 & $0.01 \sim 0.5$ & $1.3 \sim 2.0$ \\
\hline
\end{tabular}

場合を除き分散形（乳化，懸濁粒子）で使用する。高分 子物質が溶剂に溶解すると粘性を示す。塗料の製造工程 と塗装作業とを考慮して，溶液中の結合剤（固形分）は 40 60 wt \% 程度になるように溶解する。

結合剂と溶剤との相互溶解性, 経済的飞安価な溶剂を 用いたいとの要求，作業上の必要性などから，それ自体 には溶解力のない溶剤または，希釉剤で溶剤の一部を 置き变光る場合がある。40６0\% の固形分の結合剤溶 液はだいたい，粘度 1〜5〜20 ポイズ，密度 $0.9 〜 1.1$ $\mathrm{g} / \mathrm{cm}^{3}$ 程度の物性を有する。

（3）溶剤……結合剂固形分を溶液化する目的で用い られるものと，増量あるいは，作業を容易とするため 飞加えらる場合とがある。またこれらの溶剤希䣋剂に は, 低沸点, 中沸点, 高沸点のものがあって, 塗装作業 場の室温, 湿度, 次の乾燥工程の条件などにより適宜選 択し，調合されている。目的とする塗膜が得られるため そは,

1）塗料が取扱いやすい，顔料が沈降分離し難い。

2）適当な霧化粒子をつくる。

3）塗着後の流展性, 膜厚, 乾燥速度などを調節して 平坦な塗膜をつくる。

などの性質が関連している。溶剤の性質は大略, 粘度 $0.4 \sim 2.0 \mathrm{cp}$ (センチポイズ), 表面張力 $25 \sim 35 \mathrm{dyne} / \mathrm{cm}$, 密度 $0.75 \sim 0.9 \mathrm{~g} / \mathrm{cm}^{3}$ 程度のものが多い。

（参考值） 純水は粘度 $1.0 \mathrm{cp}$, 表面張力 $72 \mathrm{dyne} / \mathrm{cm}$, 密度 $1.0 \mathrm{~g} / \mathrm{cm}^{3}$

\section{（4）顔料と溶剤の標準配合例}

フタル酸（アルキド）樹脂白エナメル，ラッカー白エ ナメル,メラミン樹脂塗料の平均組成例を表- $7,8,9$ 飞 例示する。

\section{（5）霧化塗料の特性}

噴霧塗装を行なう場合は, 生塗料任 20 ～100\% のシン ナーを加光, よくかくはんして噴霧塗装を行なう。シン ナーの添加量, 添加すべき溶剤の種類をぞのように決定 するかを簡単に説明することは困難である。シンナーで
表-7 フタル酸（アルキド）樹脂白エナメル

\begin{tabular}{|c|c|c|}
\hline 原 材 料 名 & & 合 $($ wt $\%)$ \\
\hline チタン白（ルチル形） & 25 & \\
\hline 互＼cjkstart鉛＼cjkstart華 & 2 & \\
\hline 酸化形フタル酸樹脂 & 35 & (50\% 固形分) \\
\hline キ シ $\quad$ シ ン & 12 & \\
\hline ミネラルスピリット & 25 & \\
\hline 添 加 助 剂 & 1 & \\
\hline 計 & 100 & \\
\hline
\end{tabular}

表-8 ラッカー白エナメル

\begin{tabular}{|c|c|}
\hline 原 材 料 名 & 配 合 (wt \%) \\
\hline チタン白（ルチル形） & 15 \\
\hline$=ト ロ セ ル ロ-ス$ & 17 (75\% 固形分) \\
\hline ラッカー形フタル酸樹脂 & 10 (60\% 固形分) \\
\hline フタル酸ジブチル & 8（可塑剂） \\
\hline $\begin{array}{l}\text { エチングリコールモノ } \\
\text { エチルェーテル }\end{array}$ & 3 \\
\hline 酢 酸 ブ チ ル & 9 \\
\hline $\mathrm{M}$ & 5 \\
\hline $\mathrm{E}$ ブチルアルコール & 5 \\
\hline ト ル オ $\quad$ オ ル & 28 \\
\hline 計 & 100 \\
\hline
\end{tabular}

表-9 メラミン樹脂塗料の平均組成

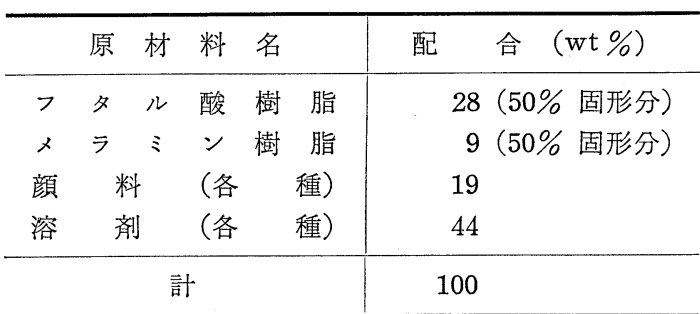

希釈すると次のような効果が得られることは理解できる であろう。
a 粘度の低下
b 表面張力の低下
c 密度の減少 (10\% 程度)
d 蒸発速度 (乾燥速度) の調節
e 体積固有抵抗值の調節

粘度の調節には, フォードカップ No. 4 を用いる。 塗料の粘度は, 普通一般のニュートン流体(水や油)の よう飞簡単な物性でなく，測定方法，特に測定時の流体 速度によって異なった值が得られる。実際に塗料を使用 するときの状態に近い測定法を考案して，粘度といいな らわしているが繳密には粘度とは全く別な性質である。 
表-10-1 希釈前の塗料の粘性（非ニュートン流体）

\begin{tabular}{|c|c|c|}
\hline 淕 料 の 種 類 & $\begin{array}{c}\text { 見掛け粘度 } \\
\text { (ポイズ) }\end{array}$ & $\begin{array}{l}\text { 降 伏 值 } \\
\text { dyne } / \mathrm{cm}^{2}\end{array}$ \\
\hline グロスエナメル & $1.4 \sim 3.9$ & $0 \sim 30$ \\
\hline セミグロスエナメル & $1.0 \sim 3.5$ & $50 \sim 120$ \\
\hline ッヤ消しェナメル & $0.6 \sim 1.0$ & $20 \sim 100$ \\
\hline 水 性 塗 料 & $0.2 \sim 1.4$ & $20 \sim 100$ \\
\hline メタルプライヤー & $0.3 \sim 1.2$ & $20 \sim 100$ \\
\hline$\nabla=ス(=ュ ー ト ン$ 流体 $)$ & $0.9 \sim 2.9$ & 0 \\
\hline
\end{tabular}

表-10-2 ラッカーを希䣋したときの不揮発分（wt％) (フォード カップ No. $4 \quad 20$ 秒 $20^{\circ} \mathrm{C}$ )

\begin{tabular}{c|c|c}
\hline $\begin{array}{c}\text { コールドスプレー用 } \\
\text { シッカーエナメル }\end{array}$ & $\begin{array}{l}\text { コールドスプレーイソリッドラ } \\
\text { 成 } \\
\text { ッカー }\end{array}$ & $\begin{array}{c}\text { ホットスプレー } \\
\text { 用ラッカー }\end{array}$ \\
\hline $15 \sim 18$ & $20 \sim 25$ & $30 \sim 35$
\end{tabular}

表-10-3 希釈された塗料の粘度 (フォード カップ No. $4 \quad 20^{\circ} \mathrm{C}$ )

\begin{tabular}{|c|c|c|}
\hline & 料 & 秒 \\
\hline & ッカーエナメル & $20 \sim 30$ \\
\hline & ラミン樹脂エナメル & $20 \sim 30$ \\
\hline & クリル樹脂エナメル & 20 \\
\hline & ポキシ樹脂エナメル & $20 \sim 25$ \\
\hline
\end{tabular}

フォードカップ No. 4 で得られる粘度は,

動粘度=絶対粘度/密度 $=$ poise または $\mathrm{cp} / \mathrm{g} / \mathrm{cm}^{3}$ と似た性質を有する。幸いにシンナーで希釈した塗料の 密度 (比重) は, 1.1 1.2 程度でめり, 顔料濃度, 樹 脂濃度もかなり小さくなるため, 塗料粘度の示す複雑さ が減少する。

噴霧塗装に実際に用いられる塗料の粘度は（フォード カップ No.4 20ㅇ) 表-10-3 からだいたい 20〜30 sec と なる。この場合は密度は $1.0 \sim 1.1 \mathrm{~g} / \mathrm{cm}^{3}$ と考兄て差支 えないから，見掛け粘度で表わすと 40８0 センチポイ ズあるいは $0.4 \sim 0.8$ ポイズ希釈によって，見掛け粘度 は直線的減少すると仮定すれば, 100\% 希釈によって, 1 ポイズの塗料は 50 センチポイズとなる。20３0\% 希 釈では, 0.7 0.8 ポイズの塗料液となることが図-5 の ように示される。密度 $\left(\mathrm{g} / \mathrm{cm}^{3}\right)$ あるいは比重の値は, 次のようにして求められる。

a 容積既知の希釈塗料を七ョウ量する

b 配合組成と希釈率より計算

c 染料の比重が既知ならば希釈率より計算

表面張力は，溶剤については前述したが，塗料の資料 はない。しかし噴霧塗料粒子の大きさに影響するのは, $\sqrt{\sigma}$ の項であるから表面張力を 64 として $\sqrt{64}=8,49$ と

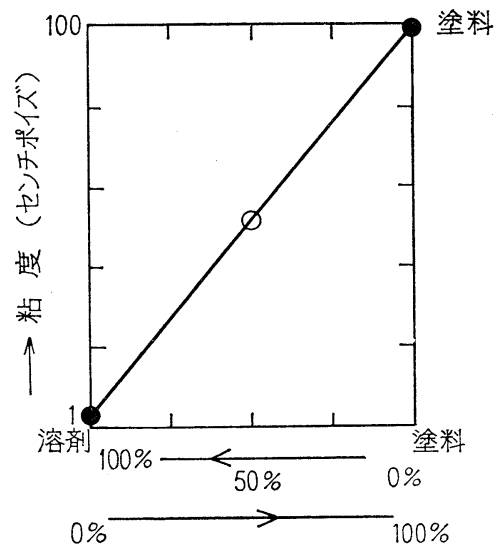

図-5＼cjkstart溶剤の混合割合と粘度

して $\sqrt{49}=7,36$ として $\sqrt{36}=6$ となる。溶剤の表面張 力は 25 35 dyne/cm である。また塗料の表面張力は 50 以下と考光られるので, 溶剤と混合して直線的に值が変 化すると仮定しても $\sqrt{\sigma}=6 \sim 7$ 程度となる。な特密度 は $\sqrt{\gamma}$ の項, $\sqrt{\sigma \gamma}$ の項に含まれるが, 前記の値より考 兄影響は少ない。

\section{(6) 塗着効率}

被塗物汇対して塗着効率の良否は, 排煙処理装置の効 率にも影響を与える。塗着効率が悪く, 飛散粉じんの多 いときは, 処理装置への負担も多く, 無䭾なコストの増 加となる。処理装置で, 粉じんを処理することよりる, 粉じんの発生を少なくして, 止むを得ないものだけ粉じ んをとるようにするのが，排煙処理の基本原則である。

被塗物泿ってい党ば, 大きい平板状の噴霧叙装対象 物の塗着率は 50〜60\% に達するが，金網のごとき場合 には数\%に止まる。静電塗装によると，金網でも $90 \%$ 近い塗着が可能となる。

一般の空気霧化塗装の塗着率は 10５0\% 程度である が，実際には対象物の大きさや，ハンガーラックに対す る吊下げ個数（相互間隔，上下間隔）コンベヤー速度， ブース内制御風速なぞに関係するので簡単には決められ ない。静電塗装では普通 $60 \sim 85 \%$, 平板状の場合は 85 〜95\% 塗着する。

\section{（7）溶剤の種類と特性}

噴霧塗装の排出口の溶剤濃度は, 指導標準では, 工場 境界線に打いて, 労働環境許容濃度の $1 / 10$, または 1 時間平均值の $1 / 100$ 以下に保つような排気筒を設置する ことを目安としている。

普通の健康な成人が 8 時間労働する環境を保護するた めに定めた濃度を, 有害物質の労働環境許容濃 度とい い,これらの施設から煙突その他によって排出されるガ 
表-11 種 類 そ 特 性

\begin{tabular}{|c|c|c|c|c|c|c|c|c|}
\hline $\begin{array}{l}\text { 化学的 } \\
\text { 分 類 }\end{array}$ & 有 機 溶 剽 名 & \begin{tabular}{|l|} 
予防 \\
規則 \\
区分
\end{tabular} & 許容濃度* & 沸 点 ${ }^{\circ} \mathrm{C}$ & 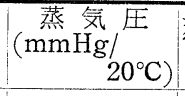 & $\left|\begin{array}{r}\text { 蒸気比重 } \\
(\text { air }=1)\end{array}\right|$ & $\begin{array}{l}\text { 爆発限界 } \\
(\text { vol \%) }\end{array}$ & $\begin{array}{l}\text { 嗅 覚 } \\
\text { の限 } \\
\text { (ppm) }\end{array}$ \\
\hline $\begin{array}{l}\text { 石 油 系 } \\
\text { 豦化水素 } \\
\text { (脂肪族) }\end{array}$ & $\begin{array}{l}n \text {-ヘキサン } \\
\text { 石油エーテル } \\
\text { ガソリン } \\
\text { 石油ナフサ } \\
\text { 石油ベンジン } \\
\text { ミネラルスピリット }\end{array}$ & $\begin{array}{l}3 \\
3 \\
3 \\
3 \\
3 \\
3\end{array}$ & $\begin{array}{l}100(500) \\
(500) \\
500 \\
(500) \\
\text { 末 } \\
\text { 末 }\end{array}$ & $\begin{array}{l}86.7 \\
30 \sim 70 \\
30 \sim 210 \\
30 \sim 200 \\
50 \sim 90 \\
150 \sim 210\end{array}$ & $150\left(24.8^{\circ} \mathrm{C}\right)$ & 2.97 & $1.2 \sim 7.5$ & \\
\hline $\begin{array}{l}\text { タール系 } \\
\text { 炭化水素 } \\
\text { (芳香族) }\end{array}$ & $\begin{array}{l}\text { コールタールナフサ } \\
\text { ベンゼン } \\
\text { トルエン } \\
\text { キシレン }\end{array}$ & $\begin{array}{l}3 \\
1 \\
2 \\
2\end{array}$ & $\begin{array}{l}(200) \\
25 \\
200 \\
150(100)\end{array}$ & $\mid \begin{array}{c}80.1 \\
110.6 \\
\text { ペラ } 138.4\end{array}$ & $\begin{array}{lr}95 . & 1\left(25^{\circ} \mathrm{C}\right) \\
30 & \left(25^{\circ} \mathrm{C}\right) \\
10 & \left(21^{\circ} \mathrm{C}\right)\end{array}$ & $\begin{array}{l}2.77 \\
3.14 \\
3.66\end{array}$ & $\begin{array}{l}1.4 \sim 7.1 \\
1.27 \sim 6.75 \\
1.1 \sim 7.0\end{array}$ & $\begin{array}{l}1.5 \\
0.48 \\
0.17\end{array}$ \\
\hline $\begin{array}{l}\text { 植 物 系 } \\
\text { 炭化水素 }\end{array}$ & テレピン油 & 3 & $(100)$ & $150 \sim 190$ & $4\left(23.6^{\circ} \mathrm{C}\right)$ & 4.7 & & 20 \\
\hline $\begin{array}{l}\text { ハロゲン } \\
\text { 炭化水菜 }\end{array}$ & 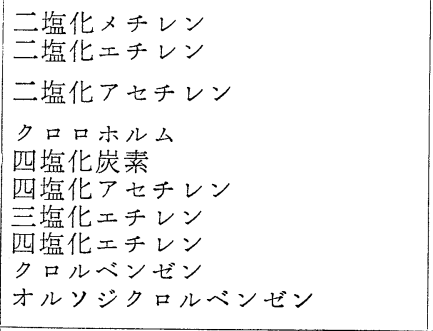 & $\begin{array}{l}2 \\
1 \\
1 \\
1 \\
1 \\
1 \\
2 \\
2 \\
2 \\
2\end{array}$ & $\begin{array}{l}500 \\
50 \\
(200) \\
50 \\
10 \\
5 \\
100 \\
(100) \\
75 \\
50\end{array}$ & 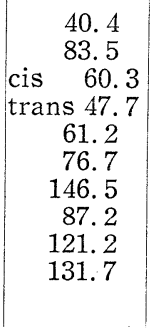 & \begin{tabular}{|l|}
348.9 \\
64 \\
\\
159.6 \\
89.6 \\
5.1 \\
57.8 \\
26.3 \\
$9 \quad\left(20^{\circ} \mathrm{C}\right)$
\end{tabular} & $\begin{array}{l}2.93 \\
3.42 \\
3.3 \\
3.3 \\
4.13 \\
5.32 \\
5.79 \\
4.54 \\
5.72 \\
3.88\end{array}$ & $\begin{array}{l}15.5 \sim 66 \\
6.2 \sim 15.9 \\
9.7 \sim 12.8 \\
9.7 \sim 12.8 \\
= \\
= \\
= \\
= \\
1.3 \sim 7.1\end{array}$ & $\begin{array}{c}674 \\
30 \\
\\
10 \\
30 \sim 50 \\
0.31\end{array}$ \\
\hline $\begin{array}{l}\text { アルニー } \\
\text { ル類 }\end{array}$ & $\begin{array}{l}\text { メタノール } \\
\text { イソプロピルアルコール } \\
\text { 第二ブチルアルコール } \\
\text { 第二ブチルアルコール } \\
\text { イソブチルアルコール } \\
\text { イソアミルアルコール } \\
\text { シクロヘキサノール } \\
\text { メチルシクロヘキサノール } \\
\text { クレゾール }\end{array}$ & $\begin{array}{l}2 \\
2 \\
2 \\
2 \\
2 \\
2 \\
2 \\
2 \\
2\end{array}$ & $\begin{array}{l}200 \\
400 \\
(100) \\
(150) \\
(100) \\
100 \\
(50) \\
(100) \\
(5)\end{array}$ & $\begin{array}{r}64.4 \\
82.3 \\
117.7 \\
99.5 \\
107.9 \\
131.4\end{array}$ & $\begin{array}{l}92 \\
32.4 \\
4.4 \\
12.7 \\
9 \\
2.3\end{array}$ & $\begin{array}{l}1.11 \\
2.07 \\
2.55 \\
2.55 \\
2.55 \\
3.04\end{array}$ & $\begin{array}{l}6.0 \sim 36.5 \\
2.0 \sim 12 \\
1.4 \sim 11.2 \\
1.7 \sim 9.8 \\
1.7 \sim 10.9 \\
1.2 \sim 9.0\end{array}$ & $\begin{array}{r}410 \\
1.9 \\
15 \\
0.003 \\
0.00026 \\
\\
0.19\end{array}$ \\
\hline ケトン類 & $\begin{array}{l}\text { アセトン } \\
\text { ×チルエチルケトン } \\
\text { ×チルイソブチルケトン } \\
\text { ×チルブチルケトン } \\
\text { シクロヘキサノン } \\
\text { メチルシクロヘキサノン }\end{array}$ & $\begin{array}{l}2 \\
2 \\
2 \\
2 \\
2 \\
2\end{array}$ & $\begin{array}{l}500(1000) \\
(200) \\
100 \\
(100) \\
(50) \\
(100)\end{array}$ & $\begin{array}{r}56.2 \\
179.6 \\
115.8 \\
127.5 \\
155.6 \\
165\end{array}$ & $\begin{array}{l}184.8 \\
71.2 \\
7.5\left(25^{\circ} \mathrm{C}\right) \\
3.8\left(25^{\circ} \mathrm{C}\right) \\
5.2\left(25^{\circ} \mathrm{C}\right) \\
3\end{array}$ & $\begin{array}{l}2.00 \\
2.49 \\
3.45 \\
\text { 3. } 45 \\
\text { 3. } 38 \\
4.86\end{array}$ & $\begin{array}{l}2.5 \sim 12.8 \\
1.8 \sim 11.5 \\
1.35 \sim 7.6 \\
1.22 \sim 8.00 \\
1.1 \sim\end{array}$ & $\begin{array}{c}1.6 \\
10 \sim 20 \\
>100 \\
>300\end{array}$ \\
\hline -テル & $\begin{array}{l}\text { エチルェーテル } \\
\text { ジオキサン } \\
\text { エチレングリコールモノメチルェ } \\
\text {-テル } \\
\text { エチレングリコールモノェチルェ } \\
\text { エテテル } \\
\text { エチレングリコールモノブチルェ } \\
\text {-テル }\end{array}$ & $\begin{array}{l}2 \\
2 \\
2 \\
2 \\
2 \\
2\end{array}$ & $\begin{array}{l}(400) \\
(100) \\
(25) \\
200 \\
(50)\end{array}$ & $\begin{array}{r}34.6 \\
101.3 \\
124.6 \\
135.6 \\
171.2\end{array}$ & $\begin{array}{l}442.2 \\
37^{\circ}\left(25^{\circ} \mathrm{C}\right) \\
6 \\
3.7 \\
0.76\end{array}$ & $\begin{array}{l}2.55 \\
3.03 \\
2.62 \\
3.10 \\
4.07\end{array}$ & $\begin{array}{l}1.9 \sim 36.5 \\
2.0 \sim 22 \\
2.5 \sim 19.8 \\
1.8 \sim 14 \\
1.1 \sim 10.6\end{array}$ & 200 \\
\hline エステル & 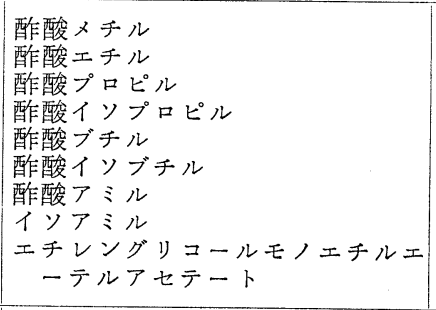 & $\begin{array}{l}2 \\
2 \\
2 \\
2 \\
2 \\
2 \\
2 \\
2 \\
2 \\
2\end{array}$ & $\begin{array}{l}200 \\
400 \\
(200) \\
(250) \\
200(150) \\
(150) \\
(100) \\
(100) \\
(100)\end{array}$ & $\begin{array}{r}57.5 \\
77.1 \\
101.6 \\
89.0 \\
126.5 \\
118.3 \\
149 \\
142 \\
145.1\end{array}$ & $\begin{array}{l}169.8 \\
74.4 \\
25.1 \\
60 \\
10.0 \\
12.9 \\
5 \quad\left(25^{\circ} \mathrm{C}\right) \\
6 \quad\left(25^{\circ} \mathrm{C}\right) \\
2.0\end{array}$ & $\begin{array}{l}2.56 \\
3.04 \\
3.54 \\
3.52 \\
4.00 \\
4.00 \\
4.49 \\
4.49 \\
4.07\end{array}$ & $\begin{array}{l}3.1 \sim 16 \\
2.2 \sim 11.4 \\
2.8 \sim 8.0 \\
1.8 \sim 7.8 \\
1.2 \sim 15 \\
1.1 \sim \\
1.0 \sim \\
1.7 \sim 8.2\end{array}$ & 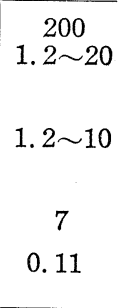 \\
\hline $\begin{array}{l}\text { イオウ } \\
\text { 誘導体 }\end{array}$ & 二硫化炭素 & 1 & 20 & 46.2 & 298 & 263 & $1.3 \sim 44$ & 0.84 \\
\hline
\end{tabular}

* 日本産業衛生協会許容濃度の勧告 (1967),（）はACGIH の勧告值 (1966) 日本の数字の横に（）がないものは 両者一致しているもの。 
ス濃度を排出濃度と呼ぶ, 排出濃度がこれ以下でなけれ ばならないという基準が排出基準であるが，環境基準と は, 老若男女が 24 時間生活するために, 環境上の条件 について, 健康を保護し, 生活環境を保全するために望 ましい基準として定めるものである。

大気污染防止法では, 本年 3 月 17 日, 政令で, 亜硫 酸ガス濃度の大気中に拈ける含有率（環境濃度）を 1 時 間値の年間最高值 $0.2 \mathrm{ppm}(1000$ 万分の 2$)$ または 1 時 間值の年間平均值 $0.06 \mathrm{ppm}$ (1000 万分の 0.6 ) とする としている。すなわち, 亜硫酸ガスの労働環境許容濃度 を $5 \mathrm{ppm}$ としているのに対し 1 時間の最高值を $1 / 25$ と し, 1 時間平均值の約 $1 / 80$ を環境濃度としているので ある。

指導標準では, 工場境界線における濃度を環境濃度と 乙て, 有機溶剂濃度は, 労働環境許容濃度の $1 / 10$ を最 高とし， 1 時間の平均值を $1 / 100$ 以下にできるような, 排気筒を設置するようにということである。 溶剤の種類と特性について表-11 に示す。

\section{5. 粉じんおよび溶剤処理施設}

\section{（1）粉じん処理施設}

塗装室（ブース）には種々の形式のものがあるが，噴 霧の粒度が $100 \sim 200 \mu$ とすると，このブースは，水洗 式または口過式のものを使用すれば, 効果があると指導 標準では述べている。また排出濃度を排気筒の出口濃度 で, 平均 $75 \mathrm{mg} / \mathrm{Nm}^{3}$, 上限 $150 \mathrm{mg} / \mathrm{N}^{3} \mathrm{~m}^{3}$ 以下とするこ とを目安としている。この目安は, 一作業期間の平均值 であって，作業休止中の測定は含んでいない。

\section{（2）水洗式スプレープース}

指導標準では乾式ブース（排気を洗浄せずにそのまま 外気に排出させる方式の施設）は認めていない。一般の 水洗式ブースは, いくつかの形式があるが特徴, 選定方 法などは省略する。(別項, 剣持氏の資料参照）

\section{（3）有機溶剤の処理施設}

排ガス中の有機溶剤を除去する方法としては，原則的 には幾多の方法が古くから考光られているが，そのうち いずれを採用するかは，その工場の立地条件，経済性， ガス中の溶剤の種類と濃度などを考慮に入れて決定すべ きである。

1）燃焼法（アフターバーナー法）

有機物は燃焼することにより酸化されて，一般には， $\mathrm{H}_{2} \mathrm{O}, \mathrm{CO}_{2}, \mathrm{~N}_{2}$ などの無害, 無臭の化合物に変化させる ことができ, 普通 $650 \sim 800^{\circ} \mathrm{C}$ の高温で完全燃焼させ る。不完全然焼のときはたとえば,ブタノールの第 1 生 成物としてブチルアルデヒドが生ずるが，これは刺激臭

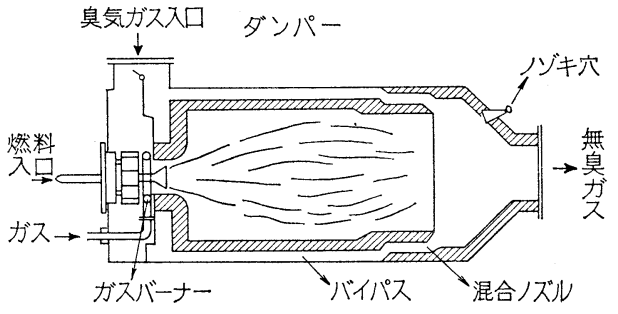

図-6 直火式燃焼炉

であり，さらに酸化が進んだときは，悪質不快な臭気を もつ酪酸となり, 最後に $\mathrm{CO}_{2}$ と $\mathrm{H}_{2} \mathrm{O}$ に分解する過程を とる。

直火による長所は, 排ガスの温度上昇による, 排気筒 出口からの拡散が大きくなることである。図-6に例を 示す。

欠点として逆火, 室内の温度上昇などがあげられる。

2）触媒酸化法

燃焼法では $800^{\circ} \mathrm{C}$ 程度の高温条件が必要であるため補 助燃料の経費が相当かかるが，触媒酸化法は白金などの 酸化触媒を使用し，低温で酸化を達成させようとする方 法で, $260 \sim 450^{\circ} \mathrm{C}$ の間に执くようにする。 $260^{\circ} \mathrm{C}$ 以下 のときは不完全燃焼を起こす可能性があり，また高温に 過ぎるときは，岕るいは有機成分の急速な酸化反応の場 合は, 触媒は過熱して効力を失なら場合がある。使用す る触媒としては磁製の棒に白金合金に活性アルミナをコ 一テングしたものや，ニクロム線に白金合金をコーテン グし，これをフィルターマット状に作られたものなどが ある。

排ガスの成分が著しく熱量を寄与するのは $1000 \mathrm{ppm}$ 以上のときであるが, 爆発限界濃度 $(10,000 \mathrm{ppm}$ 前後) 以下で操作することが大切である。

触媒酸化装置の一例を図-7 に示す。

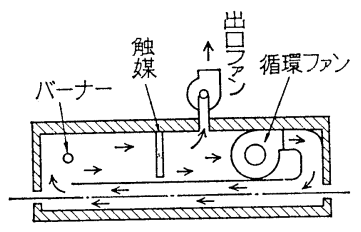

図-7 触媒酸化装置
使用例

発生源：塗料溶剤

成 分:トルエン, キシ レン,ブタノール 高級アルニール, ケトン,フェノー ル類の混合ガス

触 媒: 白金合金とアル ミナ

触媒入口温度 : $210^{\circ} \mathrm{C}($ 最 低)

触媒の寿命： 4, 000 $5,000 \mathrm{hr}$

3）吸着法

シリカゲル, 活性白土, 金属酸化物などの吸着剤は, 


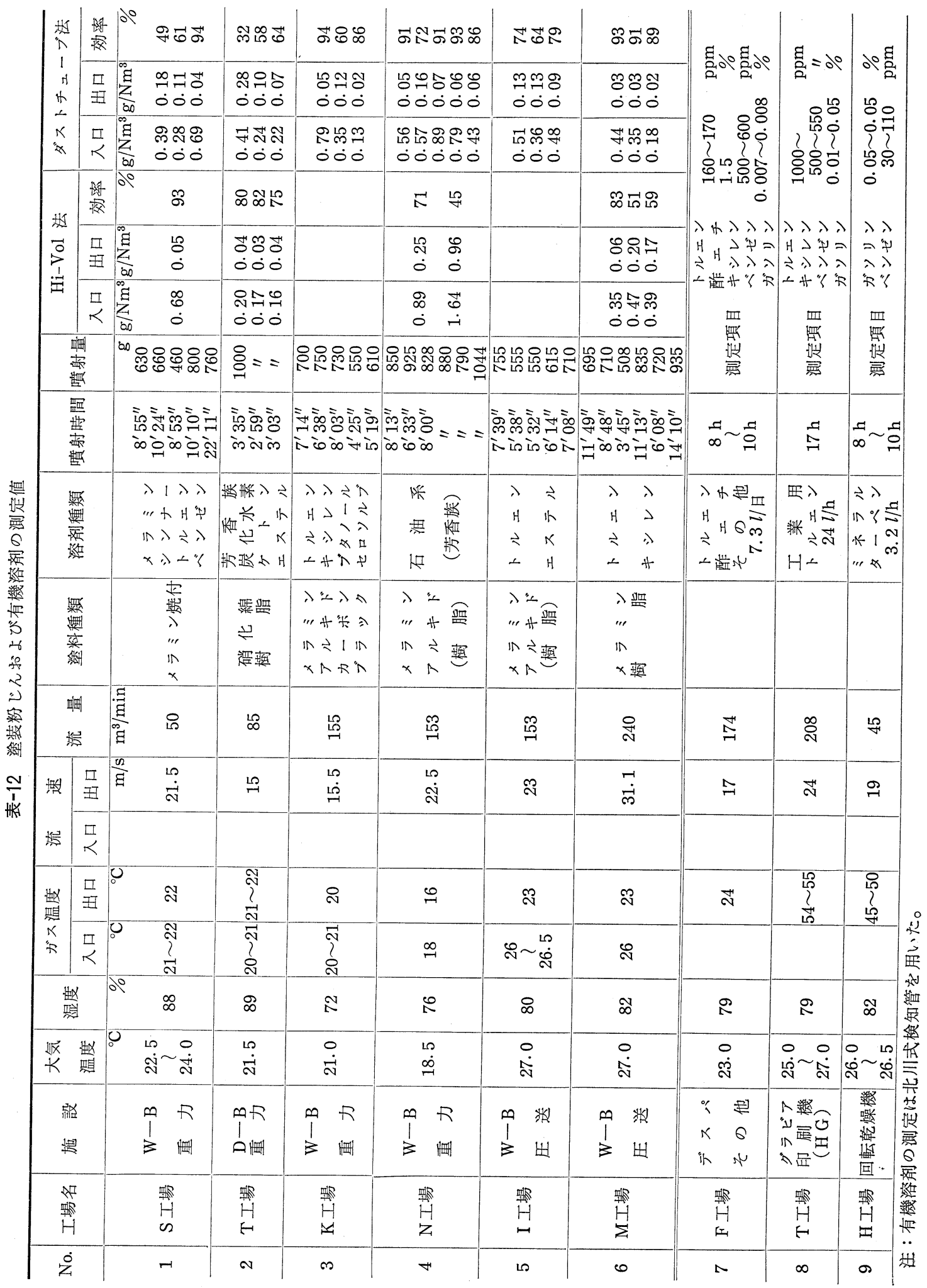




\begin{tabular}{|c|c|c|c|c|c|}
\hline \multirow{7}{*}{ 表-13 } & \multirow{7}{*}{ N工場測定例 } & \multicolumn{2}{|l|}{ 塗 } & \multicolumn{2}{|l|}{ ス プ $レ$} \\
\hline & & 式 & ウォーターブース & 式 & ワイター61(岩田製) \\
\hline & & 設 置 年 月 日 & S 37 年 11 月 & 塗料ノズル径 & $1.2 \phi \mathrm{mm}$ \\
\hline & & 施 工 者 & I 塗 装 機 & 溆料供給方法 & 重力式 吸上式 圧送式 \\
\hline & & 設＼cjkstart備 & 約 90 万 & 標準使用空気圧力 & $5.0 \mathrm{~kg} / \mathrm{cm}$ \\
\hline & & 主 要 寸 法 & 幅 3 , 高 2.2 , 奥 $2.2 \mathrm{~m}$ & 空 気 使 用量 & $125 \mathrm{l} / \mathrm{min}$ \\
\hline & & 公 称 能 力 & $300 \mathrm{cc} / \mathrm{min} \times 2$ 人 & 適 応 塗 料 & $\begin{array}{l}\text { メラミン } \\
\text { アルキド樹脂 }\end{array}$ \\
\hline 測 & 定 結 果 & 水 膜 板 面 積 & $4.5 \mathrm{~m}^{2}$ & 塗料最大塗出量 & $300 \mathrm{cc} / \mathrm{min}$ \\
\hline $\begin{array}{l}\text { 大気温度 } \\
\text { 湿 度 }\end{array}$ & $18.5^{\circ} \mathrm{C} \quad 76 \%$ & 後 室 容 積 & $14.2 \mathrm{~m}^{3}$ & パタン有効幅 & $210 \mathrm{~mm}$ \\
\hline $\begin{array}{l}\text { 排 ガ } \\
\text { 温 } \\
\end{array}$ & $\begin{array}{ll}\text { 入口 } & 18.0^{\circ} \mathrm{C} \\
\text { 出口 } & 16.5^{\circ} \mathrm{C} \\
\end{array}$ & 材 質 & 鋼, ジュラルミン(水膜部) & & \\
\hline $\begin{array}{l}\text { 施設操業 } \\
\text { 時 間 }\end{array}$ & 8 時 間 & 排気扇出力数 & $1.5 \mathrm{~kW} \times 2$ & コンプ & レッサー \\
\hline $\begin{array}{c}\text { 被塗料物 } \\
\text { 品 名 }\end{array}$ & テストピース 200 枚/日 & " 回転数 & $600 \mathrm{rpm}$ & 式 & $\begin{array}{r}\text { 日立ベビュン } 3 \phi \\
3.7 \mathrm{~kW} \\
\end{array}$ \\
\hline $\begin{array}{l}\text { ノズル } \\
\text { 空気圧力 }\end{array}$ & $1.2 \phi \mathrm{mm} \quad 5.0 \mathrm{~kg} / \mathrm{cm}$ & " 羽根直径 & $500 \mathrm{~mm}$ & 電動機出力数 & $3.7 \mathrm{~kW}$ \\
\hline $\begin{array}{l}\text { 塗料種類 } \\
\text { 色 相 }\end{array}$ & メラミン 青 & " $\quad$ " 枚数 & 4 & 作 動 圧 力 & $10 \mathrm{~kg} / \mathrm{cm}^{2}$ \\
\hline $\begin{array}{l}\text { 塗 料 } \\
\text { 賁射量 } \\
\end{array}$ & $100 \sim 125 \mathrm{cc} / \mathrm{min}$ & " 風 量 & $153 \mathrm{~m}^{3} / \mathrm{min}$ & 回 転 数 & $600 \mathrm{rpm}$ \\
\hline $\begin{array}{l}\text { 塗 料 } \\
\text { 噴射時間 }\end{array}$ & $6^{\prime} 33^{\prime \prime} \sim 8^{\prime} 00^{\prime \prime}$ & 風 圧 & $12 \mathrm{mmH}_{2} \mathrm{O}$ & 空気タンク容積 & $480 l$ \\
\hline 粉じん量 & $\begin{array}{l}\text { 入口 } \mathrm{D} T \\
0.79 \sim 0.89 \mathrm{~g} / \mathrm{Nm}^{3}\end{array}$ & 揚水ポンプ出力数 & $2.2 \mathrm{~kW}$ & & \\
\hline$\prime \prime$ & $\begin{array}{l}\text { 出口 " } \\
0.06 \sim 0.07 \quad \text { " }\end{array}$ & 使 用 水 量 & $270 \mathrm{l} / \mathrm{min}$ & 塗 料 拉 & よび 溶 剂 \\
\hline $\begin{array}{l}\text { 有 機 } \\
\text { 溶凨量 } \\
\end{array}$ & \begin{tabular}{|c|} 
入ロガソリン $0.006 \%$ \\
ガスクロ北川式 \\
\end{tabular} & 水 槽 容 積 & $2.0 \mathrm{~m}^{3}$ & 種 類（主成分） & $\begin{array}{l}\text { メラミン゙ } \\
\text { アルキド樹脂 } \\
\end{array}$ \\
\hline "I & 出口 $\quad$ " $0.005 \%$ & 排 水 水 質 & 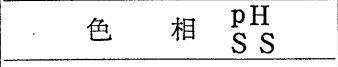 & 溶 剤（" & $\left.\begin{array}{l}\text { 石油系 } \\
\text { 芳香族系 }\end{array}\right\}$ 炭化水素 \\
\hline 処理効率 & 粉じん９1９3\% & 途 & テストピース, 色調 & 粘度 (solid solv) & $\begin{array}{lll}\text { 塗料 シン } & \text { 岩田 } \mathrm{K} \mathrm{N} \\
100 & \text { ナー } & -2 \text { カ } \\
& 20 & 23 \text { 秒 } / 19^{\circ} \mathrm{C} \\
\end{array}$ \\
\hline 塗着効率 & $50 \sim 80 \%$ & & & 途 & 車輛, ロッカー, その他 \\
\hline
\end{tabular}

2. 噴霧塗装粉じん括よび有機溶剤測定值（ただし，粉じん量 $\mathrm{g} / \mathrm{Nm}^{3}$ )

\begin{tabular}{|c|c|c|c|c|c|c|c|c|c|c|c|c|c|c|c|c|c|c|c|c|}
\hline \multirow{3}{*}{$\begin{array}{l}\text { 㭘体 } \\
\text { 採取 } \\
\text { 時間 }\end{array}$} & \multirow{3}{*}{$\begin{array}{l}\text { 検体 } \\
\text { 採取 } \\
\text { 量 } \\
\left(\mathrm{m}^{3}\right)\end{array}$} & \multirow{3}{*}{$\begin{array}{l}\text { 塗 } \\
\text { 料 } \\
\text { 噴 } \\
\text { 射 } \\
\text { 量 }\end{array}$} & \multicolumn{3}{|c|}{ Hi-Vol 法 } & \multicolumn{5}{|c|}{ 円 筒 } & \multicolumn{5}{|c|}{ ダストチューブ法 } & \multicolumn{5}{|c|}{ 有機溶剂（北川式） } \\
\hline & & & \multirow{2}{*}{$\begin{array}{c}\text { 入 } \\
\text { 口 } \\
(\mathrm{g} / \\
\left.\mathrm{Nm}^{3}\right)\end{array}$} & \multirow{2}{*}{$\left|\begin{array}{c}\text { 出 } \\
\text { 口 } \\
(\mathrm{g} / \\
\left.\mathrm{Nm}^{3}\right)\end{array}\right|$} & \multirow{2}{*}{\begin{tabular}{|c|} 
効 \\
率 \\
$(\%)$
\end{tabular}} & \multicolumn{2}{|c|}{$\begin{array}{cc}\text { 入 } & \text { 口 } \\
\left(\mathrm{g} / \mathrm{Nm}^{3}\right)\end{array}$} & \multicolumn{2}{|c|}{$\begin{array}{c}\text { 出 口 } \\
\left(\mathrm{g} / \mathrm{Nm}^{3}\right)\end{array}$} & \multirow{2}{*}{$\begin{array}{c}\text { 効 } \\
\text { 率 } \\
(\%)\end{array}$} & \multicolumn{2}{|c|}{$\begin{array}{c}\text { 入 口 } \\
\left(\mathrm{g} / \mathrm{Nm}^{3}\right)\end{array}$} & \multicolumn{2}{|c|}{$\begin{array}{|cc|}\text { 出 } & \text { 口 } \\
\left(\mathrm{g} / \mathrm{Nm}^{3}\right)\end{array}$} & \multirow{2}{*}{$\begin{array}{c}\text { 効 } \\
(\%) \\
(\%)\end{array}$} & \multicolumn{2}{|c|}{ 入口 $(\%)$} & \multicolumn{2}{|c|}{ 出口 $(\%)$} & \multirow{2}{*}{$\begin{array}{l}\text { 効 } \\
\text { 率 } \\
(\%)\end{array}$} \\
\hline & & & & & & $\left|\begin{array}{c}\text { 処理 } \\
\text { 前 }\end{array}\right|$ & $\begin{array}{c}\text { 処理 } \\
\text { 後 }\end{array}$ & $\begin{array}{c}\text { 処理 } \\
\text { 前 }\end{array}$ & 処理後 & & \begin{tabular}{|c|} 
処理 \\
前
\end{tabular} & $\left|\begin{array}{|c|}\text { 処理 } \\
\text { 後 }\end{array}\right|$ & $\begin{array}{l}\text { 処理 } \\
\text { 前 }\end{array}$ & $\left|\begin{array}{c}\text { 処理 } \\
\text { 後 }\end{array}\right|$ & & \begin{tabular}{|l|} 
ガソ \\
リン
\end{tabular} & & $\begin{array}{l}\text { ガソ } \\
\text { リソ }\end{array}$ & & \\
\hline $\begin{array}{c}13: 10 \\
? \\
13: 18\end{array}$ & $\begin{array}{l}0.2 \\
\sim 0.3\end{array}$ & 850 & 0.887 & 0.251 & 71 & & & & & & 0.586 & 0.553 & 0.042 & 0.050 & 91 & 0.004 & & 0.005 & & \\
\hline $\begin{array}{c}13: 30 \\
? \\
13: 38\end{array}$ & \begin{tabular}{|l}
0.2 \\
$\sim 0.3$
\end{tabular} & 925 & 1.643 & 0.957 & 45 & & & & & & 0.632 & 0.569 & 0.142 & 0.158 & 72 & 0.006 & & 0.003 & & \\
\hline $\begin{array}{c}13: 49 \\
? \\
13: 59\end{array}$ & $\begin{array}{l}0.2 \\
\sim 0.3\end{array}$ & 828 & & & & & & & & & 0.877 & 0.885 & 0.067 & 0.067 & 91 & & & & & \\
\hline $\begin{array}{c}14: 04 \\
? \\
14: 12\end{array}$ & $\begin{array}{l}0.2 \\
\sim 0.3\end{array}$ & 880 & & & & & & & & & 0.816 & 0.792 & 0.057 & 0.058 & 93 & 0.003 & & 0.003 & & \\
\hline $\begin{array}{c}14: 20 \\
? \\
14: 28\end{array}$ & $\begin{array}{l}0.2 \\
\sim 0.3\end{array}$ & 790 & & & & 1.252 & 0.8626 & 0.602 & 0.491 & 55 & 0.496 & 0.431 & 0.055 & 50.059 & 86 & 0.004 & & 0.003 & & \\
\hline $\begin{array}{c}14: 40 \\
\text { ? } \\
14.48\end{array}$ & $\begin{array}{l}0.2 \\
\sim 0.3\end{array}$ & 1,014 & & & & 1.001 & 0.547 & 0.617 & $(-0.078)$ & & & & & & & 0.004 & & 0.003 & & \\
\hline
\end{tabular}




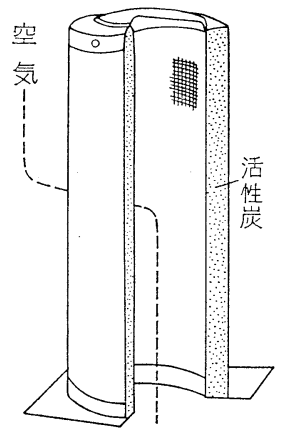

吸着剂充テン筒

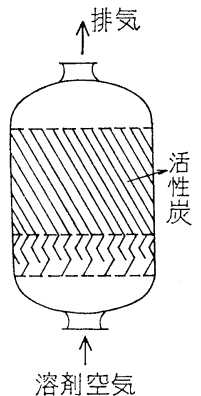

垂直式吸着塔

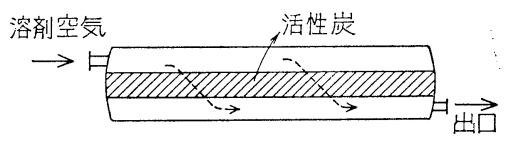

図-8 水平式吸着塔

すべて分子構造上電気的な極性を有するため，ガス中の 有機溶剂を除去するためには活性炭に限られる。

ガス流量 $700 \mathrm{l} / \mathrm{min}$ 程度の処理量に対する装置の一例 を図-8 と示す。

長所として，すべての溶剂を効率良く捕集でき，低濃 度溶剤蒸気㒀しているが，活性炭を再生する際多量の 水蒸気を必要とし，活性炭の価格も高価である。

4）吸収法

有機溶剤に対する溶解度の高い吸収液を利用して, 一 般の水洗洗浄方式と同等の方法で吸収させる。

長所として, 運転が連続であり, 吸着法のように, 吸 着, 追出しなぞの切替操作を要せず, 爆発火災の危険が なく，装置が比較的簡単であるが，短所として水以外の 吸収剂は高価であり, 処理ガス温度の低下から, 大気中 への拡散が悪くなることである。

5）凝縮法

溶剂蒸気の濃度が高い場合（1 気圧で空気中に $200 \mathrm{~g} /$ $\mathrm{m}^{3}$ 以上）にかぎられ， 1 回の凝縮では空気中に相当の 末回收溶剤蒸気を含むので循環使用するのが 普通であ る。溶剤蒸気と大気の混合気体を露点以下に冷却して, 溶剂蒸気のみを液体に変えて回収する。

長所として，純度の高い溶剂を回収することができ， 回収溶剤の精製が簡単飞行なえる。吸着法のような多量 の水蒸気を必要とせず, 施設費, 運転費は安いなどでめ るが，短所として，溶剤蒸気の濃度が高くなければなら ず，効率も吸着吸収法に比べて低く，冷凍設備なぞを必 要とする。

6）煙突の高さと拡散

煙突排ガス（排気筒出口排ガス）の大気拡散状態を推 測することは, 時間的, 季節的, 地理的に左右される気
象条件のもとで手軽に実施することは実際問題として困 難が伴う。大気拡散については多くの研究者によって, 理論式，実験式なぞが発表されている。大気污染防止法 のイオウ酸化物（亜硫酸ガス）の排出基準もこの考兄 方である。Sutton, Bosanquet \& peason, Pasquill, Liecas など排ガスの拡散と煙突高さとの関係を式で表 わしているが，その汪とんどの考方地，地上最大濃度 は, 排出ガスの污染量に正比例し, 風速敊よび, 煙突の 高さの 2 乗に反比例するといら理論である。

$$
C_{\max }=Q / \pi \cdot H^{2} u=0.318 Q / H^{2} u
$$

ここに $C_{m}=$ 地上での最大濃度

$$
\begin{aligned}
Q & =\text { 成分排出量 } \\
H_{e} & =\text { 煙突の高さ } \\
u & =\text { 平均風速 }
\end{aligned}
$$

この式はルーカスのものであるが，サットンは 0.234 を 入れて，Hを $H_{e}$ に修正している。

\section{（4）塗装粉じんおよび有機溶剤の測定例}

表-12 に東京都都市公害部において測定した塗装粉じ んおよび有機溶剤の測定例を示す。このうちN工場の例 を就せ列記する。粉じんの測定法は， JIS Z 8808 によるダストチューブ法によるものを主力とし，円筒口 紙法も使用した。また大量の粉じんを短時間に処理する ための Hi Volum 法 (ハイボリニーム法, ゲルマンフ ィルター使用）子補助に使用した。

有機溶剤の測定は，はじめ検知管法によったが，予知 された物質の単一試料としては正確さもある程度でる が，ベンゼン，トルエン，キシレンなどの混合物を 50

\begin{tabular}{|c|c|c|c|c|c|}
\hline \multicolumn{2}{|c|}{ 業 態 地 域 } & 工業 & 準工 & 商 業 & 住 居 \\
\hline \multirow{2}{*}{ 塗 } & 顔料・塗料の製造 & 0 & $\times$ & $\times$ & $x$ \\
\hline & 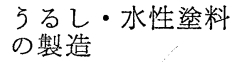 & $\bigcirc$ & 0 & 0 & 0 \\
\hline \multirow{2}{*}{ 料 } & $\begin{array}{l}\text { 油脂 (アマ=油等) } \\
\text { 加熱加工 }\end{array}$ & $\bigcirc$ & $x$ & $x$ & $x$ \\
\hline & 湮料の配合・調色 & 0 & 0 & 0 & 0 \\
\hline \multirow{2}{*}{ 洤 } & 塗料の吹 付け & 0 & 0 & $\begin{array}{c}0.75 \mathrm{~kW} \\
\text { 以下 }\end{array}$ & $x$ \\
\hline & $\begin{array}{l}\text { 塗料の加熱乾燥 } \\
\text { (ガス直) }\end{array}$ & 0 & $\bigcirc$ & $\times$ & $x$ \\
\hline \multirow[b]{2}{*}{ 装 } & " （赤外線） & 0 & 0 & $\bigcirc$ & 0 \\
\hline & $\begin{array}{l}\text { 塗料の流し塗り・ } \\
\text { 叙り }\end{array}$ & 0 & 0 & 0 & 0 \\
\hline \multicolumn{2}{|c|}{ 作 業 場 面 積 $\left(\mathrm{M}^{2}\right)$} & 0 & 0 & $\begin{array}{r}150 \mathrm{M}^{2} \\
\text { 以下 }\end{array}$ & $\begin{array}{l}50 \mathrm{M}^{2} \\
\text { 以下 }\end{array}$ \\
\hline \multicolumn{2}{|c|}{$\begin{array}{c}\text { 引火性溶剂貯蔵量 } \\
\text { (法律指定量) }\end{array}$} & O & 2 倍 & $1 / 5$ & $1 / 10$ \\
\hline
\end{tabular}
〜200ppm の濃度で作成し，ガスクロマトグラフと検知 管とで測定した結果，ガスクロは満足した結果が出たの

表-14 用途地域による作業内容の適・不適 
に対し, 検知管は作成濃度に対し, $0.85 \sim 3.0$ 倍, トルェン $2.5 \sim 18$ 倍, キシレン 10〜50 倍の高い 值となったので，測定データは削除して，ガスク ロマトグラフによるるののみを揭げた。

(5) 関係法令

表-14 に，建築基準法による工場の立地規制と して用途地域の制限を作業内容による適，不適を かかげる。

また本年 6 月に制定した東京都公害防止条例に よる, 排出基準は 10 月下旬から施行されるが, この指導標準の平均值を規制基準とする予定 $(75$ $\left.\mathrm{mg} / \mathrm{Nm}^{3}\right)$ である。

また他府県におけ和有害ガスおよび粉じんの排 出基準を表-15 亿示す。

以上東京都の公害防止の見地から大気污染に重 点を特いた指導標準について，その一部を紹介し てきた。全部を網らすることは紙面上不可能なの で, 学会の諸氏の既知のことはできるだけ本稿で 割愛してある。しかし，読み返してみると，記述 の中途半端なるのも多く, 指導標準の全ぼうを適 確に伝えていないようにるみ兄るが，その点につ いてはご容政願いたい。また, 東京都公害防止条 例は区市にも権限の一部を移譲しているので, こ の指導標準は，区拉よび市の職員にも必携のマニ ユアルトとなっている。
表-15 他府県に括活る有害ガス括よび粉じんの排出基準

\begin{tabular}{|c|c|c|c|c|c|c|c|}
\hline & 物 質 名 & 大阪府 & $\begin{array}{l}\text { 神奈川 } \\
\text { 県 }\end{array}$ & 福岡県 & 新潟県 & 兵庫県 & 宮城県 \\
\hline & アクロレイン & 0.5 & & & & & \\
\hline & アセトアルデヒド & 50 & & & & & \\
\hline & 亜 硫 酸 ガ ス & 1.5 & & 10 & 10 & 1.5 & 500 \\
\hline ガ & $\boldsymbol{\gamma} ン モ=ア$ & 30 & & 100 & 100 & 30 & 1000 \\
\hline & 塩 化 水 素 & 1.5 & 50 & 5 & 5 & 1.5 & \\
\hline z: & エチルメルカプタン & 15 & & & & & \\
\hline & ガ ソ リ ン & 150 & & & & & \\
\hline 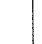 & キ シ $ン$ ン & 50 & & & & & \\
\hline の & 三 塩 化 リン & 0.2 & & & & & \\
\hline & シアン化 水素 & 3 & 10 & 10 & 10 & & 20 \\
\hline 排 & $\begin{array}{l}\text { 四塩化炭素 } \\
\text { 七ン化水素 }\end{array}$ & 0.02 & & & 50 & & \\
\hline . & 窒 素 酸 化 物 & 1.5 & 200 & 25 & 25 & 1.5 & \\
\hline 出 & トリクロルエチレン & 30 & & & 100 & & 200 \\
\hline & トル エ ン & 50 & & 20 & & 60.0 & \\
\hline & 二硫 化 炭 素 & 5 & & 35 & 20 & 6.0 & 100 \\
\hline 基 & フッ化 水素 & 1 & & & 3 & & \\
\hline & ベン ゼ ン & 10 & 3 & & 35 & 8. 0 & \\
\hline & ホス ゲ ン & 0.3 & 250 & & & & \\
\hline 準 & ホスフィン & 0.02 & & & & & \\
\hline : & ホルマリン & & & & 5 & & \\
\hline$B$ & ホルムアルデヒド & & & & & 1.5 & \\
\hline & メチルエチルケトン & 50 & 50 & & & 60 & \\
\hline & $\begin{array}{llll}\text { 硫 化 水 } & \text { 素 } \\
\text { 臭 } & & & \text { 気 }\end{array}$ & & & & $\begin{array}{l}\text { きわめて } \\
\text { 不愉快 }\end{array}$ & $\begin{array}{l}\text { (当分の間 } \\
\text { で 感 }\end{array}$ & 間 300 倍) \\
\hline & シアン化 合 物 & 1.5 & & 5 & 5 & 1.5 & 10 \\
\hline & 鉛およびその化合物 & 0.05 & & 0.15 & 0.15 & 0.05 & 0.2 \\
\hline 粉 & 硫酸 & 0.3 & & 1 & 1 & 0.3 & \\
\hline ん & フッ素化 合物 & 1.0 & & & 2.5 & 0.8 & 5 \\
\hline 排 & 亜鉛 & & & & & & \begin{tabular}{r|} 
重金属 \\
0.5
\end{tabular} \\
\hline $\begin{array}{l}\text { 出 } \\
\text { 基 }\end{array}$ & $マ$ ン ガ ン & & & & 50 & & 水銀 0.2 \\
\hline 準 & 黄リン & 0.3 & & & 0.1 & & \\
\hline$\widehat{\vec{B}}$ & 五 塩 化 リン & 0.03 & & & 1 & & \\
\hline $\overrightarrow{3}$ & ク口 $口$ 酸 & & & & 0.03 & & \\
\hline 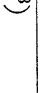 & 一般 粉 じん & & & & $\mid \begin{array}{c}400 \\
\underset{\text { 個 }}{\sim} / \mathrm{m}^{3}\end{array}$ & & \\
\hline & 備 & & $\begin{array}{l}\text { 排出口 } \\
\text { で測定 }\end{array}$ & $\begin{array}{l}\text { 認定の } \\
\text { 基準 } \\
34.4 .1\end{array}$ & 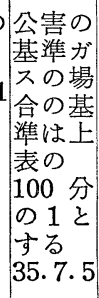 & 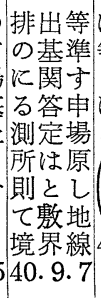 & 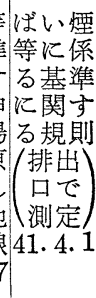 \\
\hline
\end{tabular}

